\title{
Hemşirelik Öğrencilerinin İçselleştirilmiş Kilo Önyargılarının Depresyon ve Yeme Davranışlarıyla iliş̧kisinin Belirlenmesi

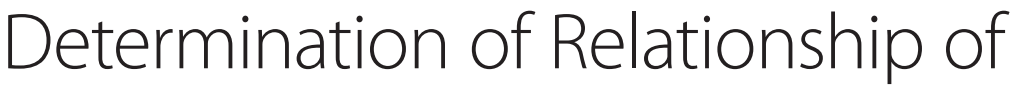 \\ Nursing Students' Internalized Weight Bias, Depression and Eating Behavior
}

\author{
(Araştırma) \\ Emine YILMAZ*, Meryeme AKSOY**
}

öz

Amaç: Bu çalışmada hemşirelik bölümü öğrencilerinin içselleştirilmiş kilo önyargı düzeyinin depresyon ve yeme davranışlarıyla ilişkisinin değerlendirilmesi amaçlanmıștır.

Gereç ve Yöntem: Tanımlayıcı tipteki araştırmada 329 öğrenciye ulaşılmıştır. Veri toplamak amacıyla Soru Formu, İçselleştirilmiş Kilo Önyargı Ölçeği, Beck Depresyon Envanteri ve Hollanda Yeme Davranışı Anketi kullanılmıștır. Verilerin analizinde sayı, yüzdelik dağılımları, ortalama, standart sapma, t testi, Pearson Korelasyon testi kullanılmıștır.

Bulgular: Araştırmaya katılanların \%73.5'inin kız, \%15.1'inin beden kitle indeksi <18.5, \% 61.7'sinin 18.5-24.9 ve \%23.2'sinin 25.0-40.0 arasında olduğu belirlenmiștir. Öğrencilerin cinsiyet durumuna göre, yeme davranışı toplam puan ortalamaları ve alt boyutlarında duygusal yeme arasında istatistiksel olarak anlamlı fark olduğu, kız öğrencilerin puan ortalamasının daha yüksek olduğu saptanmıștır. Beden kitle indeksi ve kilo önyargıları toplam puan ortalamaları arasında istatistiksel olarak anlamlı fark olduğu, sadece kilolu-obez bireylerin değil zayıf bireylerinde kilolarından dolayı kendilerini damgaladıkları belirlenmiştir. Öğrencilerin kilo önyargı ile depresyon ölçeği ve yeme davranışı toplam puanı, alt boyutlarından duygusal yeme ve kısıtlayıcı yeme arasında pozitif yönde ve anlamlı düzeyde bir ilişki olduğu saptanmıştır.

\footnotetext{
*Bingöl Üniversitesi Sağlık Bilimleri Fakültesi Psikiyatri Hemşireliği Anabilim Dalı, Bingöl, Türkiye,

E-mail: emine.tog@hotmail.com, Tel. 050617722 47, ORCID: https://orcid.org/0000-0002-8224-7300

**Atatürk Üniversitesi Hemşirelik Fakültesi Hemşirelik Esasları Anabilim Dalı, Erzurum, Türkiye,

E-mail: meryeme.aksoy@atauni.edu.tr, Tel. 044223157 95, ORCID: https://orcid.org/0000-0002-7214-7800

Geliş Tarihi: 11 Ağustos 2017, Kabul Tarihi:24 Eylül 2018

****Bu çalışma 6. Ulusal \& 2. Uluslararası Ebelik Öğrencileri Kongresinde (27-30 Nisan 2015, İstanbul) sözel bildiri olarak sunulmuştur.

Atıf/Citation: Yılmaz E., Aksoy M. Hemşirelik Öğrencilerinin İçselleştirilmiş Kilo Önyargılarının Depresyon ve Yeme Davranışlarıyla Ilişkisinin Belirlenmesi. Hacettepe Üniversitesi Hemşirelik Fakültesi Dergisi 2018; 5(3):..
} 
Sonuç: Çalışmamızda içselleştirilmiş kilo önyargı düzeyi ile depresyon, duygusal ve kısıtlayıcı yeme davranışları arasında pozitif yönde istatistiksel olarak anlamlı ilișki belirlenmiştir. İçselleştirilmiş kilo önyargı düzeyinin sadece kilolu-obez bireylerde değil aşırı zayıf bireylerde de yüksek düzeyde olduğu belirlenmiștir. Bu sonuçlar doğrultusunda; toplumdaki kiloya yönelik önyargılarla beslenen içselleştirilmiş önyargı düzeyinin kilo ile mücadelede göz ardı edilmemesi gerektiği düșünülmektedir.

Anahtar Kelimeler: Hemşire, depresyon, kilo, önyargı, yeme davranışı

\section{ABSTRACT}

Aim: The aim of study was to evaluate relationship between level of nursing students' internalized weight bias, depression and eating behaviour.

Material and method: This descriptive study was carried out with 329 students. Weight Bias Internalization Scale, Eating Behavior Questionnaire, and Beck Depression Inventory have been using during the data collection. Number, percentage mean, standard deviation, t test and Pearson's correlation test were used in the analysis of data.

Results: It was found that $73.5 \%$ were female, $15.1 \%$ of participants'body mass indeks were $<18.5,61.7 \%$ were $18.5-24.9$, and $23.2 \%$ were between $25.0-40.0$. A statistically significant difference was found between eating behaviour total scores, sub-scales emotional eating and student's gender. It was found that the higher the average score of female students. A statiscially significant correlation was also found between body mass index and weight bias, we can assert that not only obese individuals but also slim individuals stigmatize themselves because of their weights. A positive and significant correlation was found between students' total weight bias scores and total depression scores, eating behaviour's sub-scales emotional eating, restrained eating, eating behaviour total scores and weight bias.

Conclusion: In this study, a positive significant correlation was found between internalized weight bias, depression, and emotional eating and restrained eating which are among eating behaviors. When total scale scores in different weight categories were examine, we can assert that not only obese individuals but also slim individuals stigmatize themselves because of their weights. Fed to weigh the level of prejudice in the community, especially with the weight of internalized prejudice that should not be ignored in the struggle with it is considered.

Key Words: Nurse, depression, weight, bias, eating behavior

\section{GiRiş}

Obezite; kardiyovasküler, endokrin ve kanser gibi fizyolojik rahatsılıklar için önemli bir risk etkeni olmanın yanı sıra bireyin yaşam kalitesi, benlik saygısı, duygu durum bozuklukları ve yeme bozuklukları gibi psikososyal sorunlara da sebep olan önemli bir sağl1k sorunudur ${ }^{1,2}$. Obez bireylerde bu tür psikososyal faktörler genelde göz ardı edilir. Obez bireyin yaşam kalitesini etkileyen psikososyal faktörlerden biri de bireyin yaşadığı toplumun kiloya yönelik tutumları ve önyargılarıdır, tutum ve önyargılar damgalanmaya, ayrımcılığa sebep olur³. İçselleştirilmiş kilo önyargısı ise kişinin kendine yönelik önyargılarını içerir ama bu önyargıların temeli toplumun kiloya yönelik önyargılarından şekillenmektedir ${ }^{4}$. Toplum tarafından kilolu bireylere karşı oluşan önyarg1, obez bireylerin kendilerini toplum içinde ifade edememesine ve kendilerini toplumdan dışlamalarına neden olabilir. Medya ve benzeri sosyokültürel 
etkenler nedeniyle oluşan gerçek dışı güzellik kavramı kadınların kendi bedenlerinden memnun olma düzeyini azaltmakta, beden memnuniyetsizliği ile birlikte yeme bozukluklarında artışa neden olmaktadır ${ }^{5,6}$.

İçselleştirilmiş kilo önyargısı, bireyin toplumdaki olumsuz kalıp yargılarını kendisi tarafından kabullenmesi ve bunun sonucunda değersizlik, utanç gibi olumsuz duygularla kendini toplumdan geri çekmesidir ${ }^{7,8}$. Obez birey bu ayrımcılığı toplumda eğitim, istihdam, sosyalleşme gibi birçok alanda yaşamaktadır. Bireyin kilosuna göre yetenekleri, karakteri ve becerilerine karşı tutum sergilenir. Birey bu tutumlara maruz kalmamak için kendisini yaşadığı çevreden izole eder ve yalnızlaşır ${ }^{9}$. Bireyler en yaygın kilo damgalanmasını sözel olarak yaşarlar 'şişman' olarak etiketlenirler. Özellikle medyada bu bireylerin tembel, zayıf iradesiz, çekici olmayan ve oto-kontrol gücü az olan bireyler olarak tasvir edilmesi aynı zamanda batı toplumlarında zayıflık kavramının ön plana çıkması obez bireylerin dışlanmasına, çeşitli olumsuz etiketlere maruz kalmasına ve önyargılara neden olmaktadır ${ }^{8,10,11}$. Obeziteye yönelik önyargilar ve tutumlar sonucunda obez birey kendini kusurlu olarak algılar ve bu algi bireylerde duygusal yeme, kısıtlayıcı yeme davranışı bozukluğuna, zayıflama konusunda daha başarısız olmaya, motivasyon düşüklügüne ve düşük benlik saygısına sebep olur ${ }^{12,13}$. Obeziteye yönelik önyargılarla ilgili çalışmalar sınırlıdır, çünkü diğer damgalanan durumlara (mental hastalık, infertilite, AIDS vb.) nazaran kiloya yönelik damgalanmalar ve önyargılar toplumda normal ve kabul edilir bir durum olarak değerlendirilmektedir ${ }^{7}$. Pearl ve Puhl $(2014)^{14}$ çalışmalarında içselleştirilmiş önyargının sadece kilolu veya obez bireylerde değil zayıf bireylerde de görülebileceğini ortaya koymuştur. Yapılan çalışmalarda kiloya yönelik damgalandığını hisseden bireylerde yüksek depresyon, düşük benlik saygısı, intihar girişimleri, sağlıksız yeme davranışı, vücut memnuniyetsizliği arasında anlamlı ilişki saptanmıştır ${ }^{6,4,15}$.

Sağlığı korumaya ve geliştirmeye ilişkin topluma hizmet verecek ve bilinçlendirecek, rol model olacak hemşirelerin öncelikle kendilerinin sağlıklı davranış biçimi göstermeleri gereklidir. Kilo problemi yaşayan bireylerle yaşamın her alanında karşılaşma potansiyeli yüksek olan ve profesyonel sağlık ekibinde önemli görevler üstlenen hemşire adaylarının bu bireyleri yargılamadan onları damgalamadan ve ayrımcılık yapmadan bakım vermesi, gerek bakım kalitesini yükseltilmesi gerekse toplumun bu bireylere karşı sergiledikleri olumsuz tutum ve davranışlarının azaltılmasında önemlidir.

$\mathrm{Bu}$ araştırma hemşirelik bölümü öğrencilerinin içselleştirilmiş kilo önyargı düzeyinin depresyon ve yeme davranışlarıyla ilişkisini incelemek amacıyla planlanmış ve gerçekleştirilmiştir.

$\mathrm{Bu}$ amaç doğrultusunda araştırmada aşağıdaki sorulara yanıt aranmıştır:

1. Öğrencilerin içselleştirilmiş kilo önyargıları, depresyon durumu ve yeme davranışlarına etkileyen faktörler nelerdir?

2. Öğrencilerin içselleştirilmiş kilo önyargıları, depresyon durumu ve yeme davranışları arasında bir ilişki var mıdır?

\section{GEREÇ ve YÖNTEM}

\section{Araştırmanın tipi}

Araştırma tanımlayıcı tipte yapılmıştır. 


\section{Araştırmanın Evren ve Örneklemi}

Araştırmanın üniversite öğrencisi ile yapılma amacı: özelikle bu dönemdeki bireylerin ergenlik döneminde olmalarına bağlı olarak dış görünüşlerine kilo takibine önem vermeleridir. Üniversite öğrencisi olarak hemşirelik bölümü öğrencilerinin seçilmesinin nedeni örneklemin ulaşılabilirliği ve öğrencilerde kiloya yönelik damgalanma ve etkilerine yönelik farkındalık oluşturmaktır. Araştırmanın evrenini; Atatürk Üniversitesi Sağlık Bilimleri Fakültesi’nde 2015-2016 eğitim-öğretim yılında öğrenim gören hemşirelik bölümü öğrencileri oluşturmuştur. Araştırmada örneklem seçimine gidilmemiş, tüm evrene ulaşılmaya çalışılmıştır. Araştırmaya katılmayı kabul eden ve anketleri eksiksiz dolduran 242'si (\%73.5) k1z, 87’si (\%26.5) erkek toplam 329 öğrenci ile araştırma tamamlanmıştır.

\section{Veri Toplama Araçları}

Veriler araştırmacı tarafından hazırlanan ve öğrencilerin sosyo-demografik özellikleriyle ilgili bilgileri içeren Soru Formu, İçselleştirilmiş Kilo Önyarg1 Ölçeği (İKÖÖ), Beck Depresyon Ölçeği (BDÖ) ve Hollanda Yeme Davranışı Anketi (DEBQ) kullanılarak toplanmıştır

\section{Soru Formu}

Soru formu, hastaların tanıtıcı özelliklerini içeren yaş, cinsiyet, kilo ve boy olmak üzere toplam 4 sorudan oluşmaktadır.

\section{İçselleştirilmiş Kilo Ölçeği (iKöö)}

Pearl ve Puhl ${ }^{14}$ (2014) tarafından geliştirilmiş olan İKÖÖ farklı kilo kategorilerindeki bireylerin içsel önyargılarını değerlendiren bir öz bildirim ölçeğidir. Ölçek toplam 11 maddeden ve 7'li likert türünden oluşmaktadır. Ölçeğin özgün İngilizce formunun iç tutarlık katsayısı 0.94 olarak bulunmuştur. Ülkemizde ölçeğin geçerlilik güvenirlik Apay ve ark. tarafından ${ }^{16}$ (2015) yılında yapılmıştır. İKÖÖ yüksek puanlar, kişinin içselleştirilmiş kilo önyargılarının olumsuz yönde daha şiddetli olduğu anlamına gelmektedir. Bu araştırmada ölçek iç tutarlılık katsayısı ise 0.89 bulunmuştur.

\section{Beck Depresyon Envanteri (BDE)}

Sağlıklı ve psikiyatrik hasta gruplarına uygulanan, kendini değerlendirme ölçeğidir. Amacı,depresyon yönünden riski belirlemek ve depresif belirtilerin düzeyini ve şiddet değişimini ölçmektir. Toplam 21 kendini değerlendirme ölçeği içeren bu form, dörtlü Likert tipi ölçüm sağlar. Her madde 0-3 arasında giderek artan puan alır ve toplam puan bunların toplanması ile elde edilir. Toplam puanın yüksek olması depresyon şiddetinin yüksekliğini gösterir. Ölçek Beck ve arkadaşları tarafından geliştirilmiş. Ülkemizde Akdemir ve ark. ${ }^{17}$ (1996) tarafından geçerlilik ve güvenirliliği yapılmıştır. $\mathrm{Bu}$ araştırmada ölçek iç tutarlılık katsayısı ise 0.90 bulunmuştur. 


\section{Hollanda Yeme Davranışı Anketi (DEBQ)}

Van Strien, Frijters, Bergers ve Defares ${ }^{18}$ (1986) tarafından duygusal yeme, dışsal yeme, kısıtlı yeme davranışlarını ölçmek amacıyla geliştirilmiştir. Ölçek 33 maddeden oluşmakta ve 5'li derecelendirme (1= Hiçbir zaman, 5= Çok sık) ile cevaplanmaktadır. Ölçeğin Türkçe geçerlik güvenirlik çalışması Bozan, Baş ve Aşç1 ${ }^{19}$ (2011) tarafından gerçekleştirilmiştir. Yeme alışkanlıkları anketinin duygusal yeme, dışsal yeme ve kısıtlı yeme alt ölçeklerinin iç tutarlılık katsayıları sırasıyla şu şekildedir: $\alpha=.92, \alpha=.90, \alpha=.96$. $\mathrm{Bu}$ araştırmada ölçek iç tutarlılık katsayısı 0.80 bulunmuştur.

\section{Verilerin değerlendirilmesi}

Araştırma sonucunda elde edilen veriler araştırmacılar tarafından bilgisayar ortamında değerlendirilmiş ve istatistiksel çözümlemeler için SPSS 18.0 programı kullanılmıştır. Normal dağılım göstermeyen veriler için nonparametrik, gösterenler için parametrik testler kullanılmıştır. Araştırmacılar tarafından toplanan verilerin analizinde bağımsız değişkenlerin içselleştirilmiş kilo önyargı, depresyon ve yeme alışkanlıklarıyla ilişkisini incelemede ikiden fazla gruplarda Kruskal Wallis, ikili gruplarda t testi, Mann Whitney U testi analizlerinden yararlanılmıştır. İkiden fazla gruplarda farklılığın kaynaklandığı grup Bonferroni testi ile incelenmiştir Ölçekler arasındaki ilişki Pearson Korelasyon testi ile değerlendirilmiş olup, tanımlayıcı özellikler yüzdelik olarak gösterilmiştir.

\section{Araştırmanın Etik Yönü}

Araştırma öncesi, Atatürk Üniversitesi Etik Komisyon Başkanlığı’ndan etik kurul onayı alınmıştır (2015/23). Araştırmanın yapılabilmesi için öğrencilerin öğrenim gördüğü fakültenin dekanlığından yazılı izin alınmıştır. Araştırmaya katılan öğrencilere bilgilendirilmiş onam okunarak yazılı onam alınmıştır.

\section{Araştırmanın Sınırlılıkları}

Araştırmadan elde edilen bulgular sadece araştırmanın yapıldığ 1 fakültede okuyan hemşirelik öğrencilerine genellenebilir. Araştırma veri toplama araçlarının uygulandığı tarihlerde okula devamsızlık yapmayan ve araştırmaya katılmayı kabul eden öğrencilerden elde edilen verilerle sınırlıdır.

\section{BULGULAR}

Hemşirelik bölümü öğrencilerinin içselleştirilmiş kilo önyargılarının, depresyon düzeyi ve yeme davranışları ile ilişkisinin incelendiği çalışmamızda; öğrencilerin

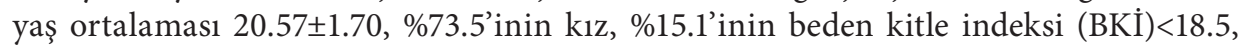
\%61.7'sinin BKİ 18.5-24.9 ve \% 23.2'sinin BKİ 25.0-40.0 arasında olduğu, ölçeklerin puan ortalamaları ise; İKÖÖ puan ortalaması $25.50 \pm 14.02$, BDE puan ortalaması $11.84 \pm 10.57$ olarak belirlenmiştir. DEBQ puan ortalamaları $85.18 \pm 18.30$ olup, alt ölçeklerinden

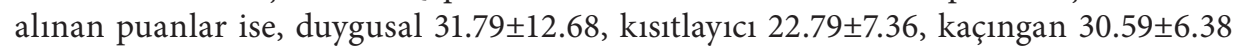
olarak belirlenmiştir. 
Öğrencilerin tanımlayıcı özelliklerine göre; İKÖÖ, BDE ile DEBQ ve alt boyut puan ortalamaları karşılaştırıldığında; Öğrencilerin cinsiyete göre; İKÖÖ, BDE ile DEBQ’nun kısıtlayıcı ve dışsal yeme alt boyutunun puan ortalamaları arasında istatistiksel olarak anlamlı fark olmadığı belirlenmiştir ( $\mathrm{p}>0.05)$. Öğrencilerin cinsiyet durumuna göre, DEBQ toplam puan ortalamaları ve alt boyutlarında duygusal yeme arasında istatistiksel olarak anlamlı fark olduğu, kız öğrencilerin puan ortalamasının daha yüksek olduğu saptanmıştır. Öğrencilerin yaş grubuna göre, İKÖÖ, BDE, DEBQ ve üç alt boyutunun puan ortalamaları arasında istatistiksel olarak anlamlı fark olmadığı belirlenmiştir. Öğrencilerin BKİ durumuna göre, BKİ, BDE ve DEBQ’nun dışsal yeme alt boyutunun puan ortalamaları arasında istatistiksel olarak anlamlı fark olmadığ 1 belirlenmiştir ( $p>0.05$, Tablo 3). BKİ ve İKÖÖ toplam puan ortalamaları arasında istatistiksel olarak anlamlı fark olduğu, yapılan ileri analizde (Bonferroni) bu farkın zayıf ve kilolu-obez bireylerden kaynaklandığı saptanmıştır. Öğrencilerin BKİ durumuna göre, DEBQ’nun duygusal yeme alt boyutu toplam puan ortalamaları arasında istatistiksel olarak anlamlı fark olduğu, yapılan ileri analizde (Bonferroni) bu farkın zayıf ve kilolu-obez bireylerden kaynaklandığı saptanmıştır (Tablo 1).

Öğrencilerin İKÖÖ, BDE ile DEBQ ve alt boyutları puanları arasındaki ilişki incelendiğinde; öğrencilerin İKÖÖ toplam puanları ile BDE toplam puanları arasında pozitif yönde, anlamlı ve zayıf düzeyde bir ilişki olduğu saptanmıştır $(r=0.21, p<0.001)$. DEBQ alt boyutlarindan duygusal yeme $(\mathrm{r}=0.12, \mathrm{p}<0.05)$, kisitlayıcı yeme $(\mathrm{r}=0.25$, $\mathrm{p}<0.01)$, DEBQ toplam puanları $(\mathrm{r}=0.17, \mathrm{p}<0.01)$ ile İKÖÖ arasında pozitif yönde, anlamlı ve zayıf düzeyde bir ilişki olduğu bulunmuştur. Öğrencilerin BDE puanları ile DEBQ ve alt boyutları puanları arasında ise istatistiksel olarak bir ilişki olmadığı bulunmuştur (Tablo 2).

\section{TARTIŞMA}

Hemşirelik bölümü öğrencilerinin içselleştirilmiş kilo önyargılarının, depresyon düzeyi ve yeme davranışlarıyla ilişkisinin incelendiği çalışmamızda; duygusal yeme (kişinin içinde bulunduğu ruh halinin yemek yeme biçimi üzerindeki etkisi) puan ortalaması kız öğrencilerde, zayıf ve kilolu-obez bireylerde yüksek düzeylerde bulunmuştur. Snoek ve ark.7 (2008) yürüttüğü çalışmada kızlarda duygusal yeme oranı yüksek düzeylerdeyken; erkeklerde daha çok dişsal yeme oranı yüksek düzeyde bulunmuştur. Braet ve ark. ${ }^{20}$ (2008) yaptığı çalışmada da aşırı kilolu olan genç kızlar daha fazla duygusal yeme davranışı gösterdiği belirlenmiştir. Yapılan çalışmalarda duygu durum bozukluklarının kadınlarda daha fazla saptandığı düşünüldüğünde ve ister olumlu ister olumsuz nitelikte olsun, emosyonel uyarının yeme davranışı değişikliklerine yol açtığ yüksek olması aslında beklenilen bir durumdur ${ }^{3,21}$. Olumsuz emosyonlar veya stres durumunda gözlenen fizyolojik reaksiyonlar beslenme sonrası oluşan tokluk hissine benzerliği kabul edilmiştir. Aynı zamanda emosyonel yemenin beden kitle indeksi düşük ve beden kitle indeksi yüksek kişilerde daha sık görüldüğü ortaya konmuştur ${ }^{22}$. BKİ düşük bireyler BKİ yüksek bireylerde olduğu gibi hem olumsuz beden algısına eşlik eden olumsuz duygulardan hem de genel yaşamda yaşantıladıkları olumsuz duygularla baş etme yöntemi olarak duygusal yemeye yönelmektedir. Duygusal yemeyi etkileyen faktörlerden biri de ideal fiziksel görünüm ile ilgili sosyokültürel baskılardır ${ }^{23}$. 
Tablo 1. Tanımlayıcı özelliklere göre içselleștirilmiş kilo önyargı, Beck depresyon ölçeği, yeme davranışları anketi ve alt boyutları puan ortalamalarının karşılaştırılması

\begin{tabular}{|c|c|c|c|c|c|c|c|c|}
\hline \multirow{3}{*}{ Özellikler } & \multirow{3}{*}{$\mathbf{n}$} & \multirow{3}{*}{$\%$} & İKÖÖ & BDE & \multicolumn{4}{|c|}{ Yeme Davranışı Anketi Alt Boyutları } \\
\hline & & & \multirow[b]{2}{*}{ Ort. \pm Ss } & \multirow[b]{2}{*}{ Ort. \pm Ss } & Duygusal & Kısıtlayıcı & Dişsal & Toplam \\
\hline & & & & & Ort. \pm Ss & Ort. \pm Ss & Ort. \pm Ss & Ort. \pm Ss \\
\hline \multicolumn{9}{|l|}{ Cinsiyet } \\
\hline Kadın & 242 & 73.5 & $25.98 \pm 14.26$ & $11.84 \pm 10.44$ & $33.90 \pm 14.79$ & $23.41 \pm 7.71$ & $31.08 \pm 6.50$ & $88.40 \pm 19.17$ \\
\hline \multirow{3}{*}{ Erkek } & \multirow{3}{*}{87} & \multirow{3}{*}{26.5} & $23.91 \pm 13.05$ & $11.83 \pm 11.16$ & $27.46 \pm 11.17$ & $21.59 \pm 7.98$ & $30.30 \pm 7.75$ & $79.84 \pm 20.02$ \\
\hline & & & $\mathrm{U}=570$ & $U=603$ & $\mathrm{U}=0.463$ & $\mathrm{U}=536$ & $\mathrm{U}=607$ & $\mathrm{~T}=978$ \\
\hline & & & $p=0.255$ & $p=0.819$ & $P=0.002$ & $P=0.750$ & $P=0.643$ & $P=0.002$ \\
\hline \multicolumn{9}{|l|}{ Yaş } \\
\hline $17-20$ & 106 & 32.2 & $26.56 \pm 15.63$ & $10.38 \pm 8.09$ & $33.06 \pm 14.56$ & $22.56 \pm 7.95$ & $30.84 \pm 6.70$ & $86.47 \pm 20.24$ \\
\hline $20-23$ & 177 & 53.7 & $25.49 \pm 13.68$ & $12.09 \pm 10.74$ & $32.84 \pm 14.63$ & $23.10 \pm 7.68$ & $31.04 \pm 6.84$ & $87.22 \pm 19.74$ \\
\hline \multirow{3}{*}{$23-27$} & \multirow{3}{*}{46} & \multirow{3}{*}{13.9} & $23.03 \pm 11.23$ & $14.38 \pm 14.06$ & $29.38 \pm 11.40$ & $24.03 \pm 8.21$ & $29.88 \pm 6.64$ & $83.30 \pm 17.20$ \\
\hline & & & KW:1.778 & $\mathrm{KW}=0.275$ & $K W=0.990$ & $\mathrm{KW}=0.769$ & $\mathrm{KW}=1.058$ & $K W=0.283$ \\
\hline & & & $P=0.678$ & $P=0.872$ & $P=0.610$ & $P=0.681$ & $P=0.589$ & $P=0.868$ \\
\hline \multicolumn{9}{|l|}{ BKi } \\
\hline$<18.5$ (zayıf) & 50 & 15.1 & $25.76 \pm 12.26$ & $11.24 \pm 8.42$ & $26.56 \pm 10.15$ & $19.10 \pm 6.48$ & $32.73 \pm 7.35$ & $78.40 \pm 15.47$ \\
\hline $\begin{array}{l}18.5-24.9 \\
\text { (normal) }\end{array}$ & 203 & 61.7 & $23.40 \pm 13.03$ & $11.65 \pm 10.53$ & $33.09 \pm 14.94$ & $22.79 \pm 7.54$ & $30.76 \pm 6.60$ & $86.85 \pm 19.96$ \\
\hline \multirow{2}{*}{$\begin{array}{l}25.0-40.0 \\
\text { (obez ve } \\
\text { fazla kilolu) }\end{array}$} & 76 & 23.2 & $34.93 \pm 15.66$ & $13.02 \pm 12.01$ & $34.21 \pm 13.17$ & $26.73 \pm 8.24$ & $30.19 \pm 7.05$ & $91.15 \pm 19.23$ \\
\hline & & & $\begin{array}{c}F=846 \\
P=0.000\end{array}$ & $\begin{array}{l}K W=362 \\
P=0.696\end{array}$ & $\begin{array}{c}F=118 \\
P=0.046\end{array}$ & $\begin{array}{l}K W=686 \\
P=0.000\end{array}$ & $\begin{array}{l}K W=391 \\
P=0.251\end{array}$ & $\begin{array}{c}F=954 \\
P=0.020\end{array}$ \\
\hline
\end{tabular}

Tablo 2. İçselleştirilmiş kilo önyargı, Beck depresyon envanteri ve yeme davranışları anketi ve alt boyutları arasındaki ilişki

\begin{tabular}{|c|c|c|c|c|}
\hline Ölçekler & \multicolumn{2}{|c|}{ BDE } & \multicolumn{2}{|c|}{ İKöö } \\
\hline İKÖÖ & $r=0.216^{* *}$ & & & \\
\hline \multicolumn{5}{|l|}{ DEBQ } \\
\hline Duygusal yeme & $r=0.044$ & $p=0.295$ & $r=1.288^{*}$ & $p=0.033$ \\
\hline Kısıtlayıcı yeme & $r=0.024$ & $p=0.590$ & $r=2.249 * *$ & $\mathrm{p}=.0000$ \\
\hline Dışsal yeme & $r=0.067$ & $p=0.110$ & $r=0.032$ & $p=0.450$ \\
\hline Ölçek toplam & $r=0.077$ & $p=0.062$ & $r=0.181^{* *}$ & $p=0.000$ \\
\hline
\end{tabular}


Toplumun obez bireylere yönelik önyargı ve genel olumsuz bakış açısı bu grubun sosyal ilişkilerini, iş hayatında terfi durumlarını ve eğitimini olumsuz etkilemekte ${ }^{24}$. Özellikle medyada bu bireylerin tembel, zayıf iradeli, çekici olmayan ve oto-kontrol gücü daha az olan bireyler olarak tasvir edilmesi bu bireylerin duygu durumunu etkileyip duygusal yemeye sürüklemekte ve bireylerin bu önyargıları içselleştirmesine sebep olmaktadır³. Yapılan çalışmalarda sadece kilolu-obez bireylerde değil toplumda kiloya yönelik önyargıları içselleştiren yaşanılan kültürdeki ideal görünüme sahip olamayan BKİ $\leq 18.5$ olan bireylerde de duygusal yeme davranışı ve içselleştirilmiş kilo önyargıları yüksek düzeyde bulunmuştur ${ }^{14,25,26}$. Çalışmamızda da içselleştirilmiş kilo önyarg1 düzeyi zayıf ve kilolu-obez bireylerde yüksek bulunmuştur bu bulgular önceki çalışmalarla tutarlılık göstermektedir.

Çalışmamızdaki çarpıcı bulgulardan biri de içselleştirilmiş kilo önyargı düzeyi, depresyon, duygusal yeme ve kisitlayıcı yeme (bireyin kilosunu denetim altında tutmak amaciyla yediği besinleri kısıtlama eğilimi) arasındaki zayıf düzeyde bile olsa pozitif yönde bulunan ilişkidir. Öğrencilerin kilo ile ilgili içsel önyargıları arttıkça depresyon düzeyi de artmakta aynı zamanda daha fazla kısıtlayıcı ve duygusal yeme davranışı sergilemektedirler. Yapılan çalışmalarda, kiloya yönelik damgalandığını hisseden bireylerde yüksek depresyon, düşük benlik saygısı, intihar girişimleri, sağlıksız kilo kontrolü, vücut memnuniyetsizliği arasında anlamlı ilişki saptanmıştır ${ }^{27,28}$. Damgalanma, bireyin sosyal kimliğini de tehdit etmektedir, toplumun diğer bireyleri tarafından sosyal bir kategoride (aşırı zayıf/aşırı kilolu=olumsuz mitler) etiketlenen birey, bu sosyal kimliğinden dolayı anksiyete ve stresi artar, kişinin öz kontrolü düşer depresyona girer bu duygular da bireyi daha fazla yemeye sürükler ${ }^{21}$. Thomson ve ark.6 (2017) 300 adölesanla yaptığ 1 çalışmada kiloya yönelik içsel önyargıların duygusal yemeye sebep olduğu belirlenmiştir. Stewens ve ark. ${ }^{5}$ 299 kişiyle yaptığ belirlenmiştir. Benzer bir şekilde Salwen ve ark. ${ }^{29}$ (2015) kiloya yönelik damgalanma ve önyargıların bireylerde duygusal yeme, kısıtlayıcı yeme ve gece yeme sendromu gibi yeme bozukluklarına sebep olduğu bulunmuştur.

\section{SONUÇ ve ÖNERILER}

Sonuç olarak çalışmamızda toplumda kiloya yönelik önyargıları içselleştiren bireylerde depresyon düzeyinin yüksek olduğu aynı zamanda bu bireylerde duygusal ve kısıtlayıcı yeme gibi yeme davranışı bozukluğu görüldüğü belirlenmiştir. Aynı zamanda içselleştirilmiş kilo önyargı düzeyinin sadece kilolu-obez bireylerde değil aşırı zayıf bireylerde de yüksek düzeyde olduğu belirlenmiştir. Bireyin sağlığının korunması, yükseltilmesi ve toplum sağlı̆̆ının geliştirilmesinde önemli rolü olan hemşireler henüz meslek yaşamına başlamadan, öğrencilik dönemlerinde kiloya yönelik ön yargı düzeylerinin ve farkındalıklarının belirlenmesi, ön yargı düzeyi yüksek olan bölümlerin ders müfredatında obezite, ön yargı ve yol açtığg sorunlara yönelik konulara yer verilmesi önerilebilir.

Çalışma sonuçları özellikle toplumdaki kiloya yönelik önyargılarla beslenen içselleştirilmiş önyargı düzeyinin kilo ile mücadelede göz ardı edilmemesi gerektiğini, toplumda özellikle bu konuyla ilgili farkındalığın arttırılması ve medyanın bilinçlendirilmesinin özellikle kilo problemi olan bireylerin duygu durumunu, yaşam kalitesini ve kiloya yönelik tedavi sürecini olumlu etkileyebileceğini düşündürmektedir. 


\section{KAYNAKLAR}

1. Beck AR. Psychosocial Aspects of Obesity. NASN School Nurse. 2016;31(1):23-7.

2. White MA, O'neil PM, Kolotkin RL, Byrne TK. Gender, Race, and Obesity-Related Quality of Life at Extreme Levels of Obesity. Obesity Research. 2004;12(6):949-55.

3. Friedman KE, Ashmore JA, Applegate KL. Recent experiences of weight based stigmatization in a weight loss surgery population: psychological and behavioral correlates. Obesity. 2008;16(S2).

4. Puhl RM, Moss-Racusin CA, Schwartz MB. Internalization of weight bias: Implications for binge eating and emotional well-being. Obesity. 2007;15(1):19-23.

5. Stevens SD, Herbozo S, Morrell HE, Schaefer LM, Thompson JK. Adult and childhood weight influence body image and depression through weight stigmatization. Journal of health psychology. 2016:1359105315624749.

6. Thompson KA, Kelly NR, Schvey NA, Brady SM, Courville AB, Tanofsky-Kraff M, et al. Internalization of appearance ideals mediates the relationship between appearance-related pressures from peers and emotional eating among adolescent boys and girls. Eating behaviors. 2017;24:66-73.

7. Snoek HM, van Strien T, Janssens JM, Engels RC. Restrained eating and BMI: a longitudinal study among adolescents. Health Psychology. 2008;27(6):753.

8. Reilly A, NA. R. Is internalized homonegativity related to body image. Fam Consum Sci Res J 2006;35:5873. .

9. Schey N.A., White M.A. The internalization of weight bias associated with severe eating pathology among lean individuals. Eating behaviors. 2015;17:1-5.

10. Schwartz MB, Neal H, Brownell KD, Blair S, Billington C. Weight bias among health professionals specializing in obesity. Obes Res. 2003;11:1033-9.

11. Schamer T, Johns M., Forbes C. An integrated process model of stereotype threat effects on performance. psychological rewiew. 2008;115:336-56.

12. Pervanidou P, Bastaki D, Chouliaras G, Papanikolaou K, Laios E, Kanaka-Gantenbein C, et al. Circadian cortisol profiles, anxiety and depressive symptomatology, and body mass index in a clinical population of obese children. Stress. 2013;16(1):34-43.

13. Crister G. FatLand:HowAmericansBecametheFattestPeople in the World. New York: Houghton Mifflin Company;2004.

14. Pearl R.L, Puhl R.M. Measuring internalized weight attitudes across body weight categories: Validation of the Weight Bias Internalization Scale. Body Image. 2014;11(1):89-92.

15. Wee CC, Davis RB, Chiodi S, Huskey KW, . HM. Sex, Race, and the Adverse Effects of Social Stigma vs. Other Quality of Life Factors Among Primary Care Patients with Moderate to Severe Obesity. Society of General Internal Medicine. 2014.

16. Apay SE, Yılmaz E, Aksoy M, Akalın H. Turkish Validity and Reliability Study of Modified Weight Bias Internalization Scale. 18th Conference of the International Society of Psychosomatic Obstetrics and Gynaecology (2016), Book of abstracts, Malaga, Spain.

17. Akdemir A, Örsel S, Dağ İ ve ark. (1996) Hamilton depresyon derecelendirme ölçeği (HDDÖ)'nin geçerliliği, güvenilirliği ve klinikte kullanımı. Psikiyatri Psikoloji Psikofarmakoloji Dergisi, 4:251-9.

18. Van Strein T, Frijters J, Bergers G, Defares P. The Dutch eating behaviour questionnaire (DEBQ) for assesment of restrained, emotional and external eating behaviour. International Journal of Eating Disorder, 1986;5: 295-315

19. Bozan N, Baş M, Aşçı H. Pscyhometric properties of Turkish version of Dutch eating behaviour questionnaire (DEBQ). A preliminary results. Appetite, 56, 564-566. 
20. Braet C, Claus L, Goossens L, Moens E, Van Vlierberghe L, Soetens B. Differences in eating style between overweight and normal-weight youngsters. Journal of health psychology. 2008;13(6):733-43.

21. Ashmore JA, Friedman KE, Reichmann SK, Musante GJ. Weight-based stigmatization, psychological distress, \& binge eating behavior among obese treatment-seeking adults. Eating Behaviors. 2008;9(2):203-9.

22. Puhl R, KD B. Bias, discrimination, and obesity. Obes Res. 2001;9:788-805.

23. Puhl RM, CA. H. Obesity stigma: important considerations for public health. Am J Public Health. 2010;100:1019-28.

24. Puhl RM, Latner JD. Stigma, obesity, and the health of the nation's children. Psychol Bull 2007;133:55780.

25. Puhl RM, Moss-Racusin CA, Schwartz MB. Internalization of weight bias: Implications for binge eating and emotional well-being. Obesity (Silver Spring). 2007;15(19-23).

26. Lillis J, Levin ME, Hayes SC. Exploring the relationship between body mass index and health-related quality of life: A pilot study of the impact of weight self-stigma and experiential avoidance. Journal of Health Psychology. 2011;16(5):722-7.

27. Major B, Hunger JM, Bunyan DP, Miller CT. The ironic effects of weight stigma. Journal of Experimental Social Psychology. 2014;51:74-80.

28. Wott CB, Carels RA. Overt weight stigma, psychological distress and weight loss treatment outcomes. Journal of health psychology. 2010;15(4):608-14.

29. Salwen JK, Hymowitz GF, Bannon SM, O'Leary KD. Weight-related abuse: perceived emotional impact and the effect on disordered eating. Child abuse \& neglect. 2015;45:163-71. 